\title{
Factors influencing livestock export in Somaliland's terminal markets
}

\author{
Ahmed M. Musa ${ }^{1 *}$ (D), Oliver Vivian Wasonga ${ }^{1}$ and Nadhem Mtimet $^{2}$
}

\begin{abstract}
Livestock export from Somaliland to the Arabian Peninsula countries is an important economic activity and the main source of Somaliland's foreign exchange earnings. We have employed multiple regression time series analysis of secondary data to understand factors that influence the monthly volumes of small ruminants (sheep and goats) and cattle traded for export in three terminal markets in Somaliland. Results show that the Hajj season, number of livestock exporters active in the markets, market location and livestock ban imposed by the import countries are the main factors that influence the monthly volume of livestock transacted for export. Further, the results indicate that though drought does not influence the volume of small ruminants, it has an influence on the volume of cattle, while the implementation of quarantine stations has a significant influence on the volumes of livestock exports. Finally, border restrictions imposed by Ethiopia do not influence the volume of livestock transacted for export in the study markets. Most of the factors analysed to have influence on monthly volume livestock transacted for export are institutional and policy-related hence can be corrected though requisite regulatory, institutional and policy reforms in consultations with stakeholders.
\end{abstract}

Keywords: Cattle and small ruminant export, Livestock ban, Terminal markets, Quarantine stations, Somaliland

\section{Introduction}

Livestock trade is one of the Horn of Africa's (HoA) economic success stories (Little et al. 2015). This indicates that the agricultural sector, and in particular livestock industry, has potential for economic growth in sub-Saharan Africa (Diao et al. 2010). It is estimated that the value of annual livestock export, including cross-border export between HoA countries, is US\$1 billion (Catley et al. 2013; Little et al. 2015). The region's proximity to the Arabian Peninsula markets, the largest market for live animal trade (Knips 2004), offers a potential opportunity for live animal exports. Majid (2010) reported that livestock export from Somalia, including Somaliland, is the largest concentration of live animal export in the world. ${ }^{1}$ Live animal export is

\footnotetext{
${ }^{1}$ Somaliland, former British protectorate, has unilaterally declared its independence from Somalia in 1991, but it is internationally recognised as part of Somalia. It borders Djibouti to the northwest, Ethiopia to the southwest, south-central Somalia to the east and Gulf of Aden in Yemen to the north.
}

\footnotetext{
* Correspondence: ahmedbrown.musa@gmail.com

'Department of Land Resource Management and Agricultural Technology (LARMAT), University of Nairobi, PO Box 29053-00625, Nairobi, Kenya

Full list of author information is available at the end of the article
}

vital for Somaliland's economy, contributing $85 \%$ of export earnings and 30\% of the Gross Domestic Product (GDP) and directly and indirectly employs $70 \%$ of the population (Mugunieri et al. 2016).

Due to the imposition of repeated livestock export bans by the Arabian Peninsula countries, and recurrent droughts, Somaliland has experienced boom and bust cycles in livestock export volumes, therefore making the country's macro-economy volatile (Ministry of National Planning and Development 2017). Many times, drought could affect Somaliland more than eastern Ethiopia, and therefore, given that 50\% of the animals (mainly sheep and goats) exported through Somaliland's port of Berbera come from the Somali region of Ethiopia, the numbers exported may not be significantly affected despite the drought experienced in Somaliland. The repeated bans on livestock exports from Somalia presented an opportunity for other countries in the region such as Djibouti and Ethiopia to supply livestock to the Arabian Peninsula markets (Aklilu 2008; Majid 2010; Eid 2014). In its effort to restore the confidence of the import countries, Somaliland established and privatised quarantine 
stations and its export livestock certification system in 2009 to a Saudi investor and few months later Saudi Arabia lifted the protracted 2000-2009 livestock ban (Eid 2014). At the same time, neighbouring Ethiopia and Djibouti also installed quarantine stations (Majid 2010; Eid 2014). However, Saudi importers still prefer Berbera port due to, inter alia, the presence of modern quarantine stations (Little et al. 2015). Middle livestock traders (jeebles) also prefer Somaliland's terminal markets due to the concentration of larger livestock exporters (Umar and Baulch 2007).

Togwajale, Hargeisa and Burao terminal markets in Somaliland attract livestock for export from Somaliland, eastern Ethiopia and south-central Somalia. Although there is a great body of literature on Somalia/Somaliland's livestock exports (see for instance Negassa et al. 2008; Mugunieri et al. 2008; Godiah et al. 2014), there is little that quantifies the factors that influence the volume of livestock traded for export. Therefore, in this contribution, we aim to fill this gap by attempting to identify and quantify the factors influencing livestock traded for export from the local terminal markets in Somaliland. The findings will inform policy-makers in Somaliland, and beyond in the HoA, to understand the key factors influencing livestock traded for export for policy prioritisation.

\section{Trends in the number of livestock export in Somaliland}

The Kingdom of Saudi Arabia (KSA), Yemen, Oman and the United Arab Emirates (UAE) are the main destinations for Somaliland livestock exports. Saudi Arabia is the main destination for small ruminant (sheep and goats) exports as $70 \%$ of the export takes place during the Muslim Hajj season (Majid 2010). Yemen and Oman are two major destinations for cattle exports. Trend analysis of the yearly and monthly number of livestock export from the port of Berbera is provided in Figs. 1 and 2. The results in Fig. 1 indicate that livestock bans were responsible for the sharp decreases in livestock export volumes. As will be explained, based on health grounds, import countries imposed several bans on livestock exports from Somalia's ports. Saudi Arabia was responsible for most of the bans based on claims that it found Rift Valley fever (RVF) on Somali livestock; therefore, the analysis reveals that the ban imposed by Saudi Arabia had caused sharp falls in the volumes of small ruminants' export.

Figure 2 indicates monthly peaks in livestock export during the Muslim Hajj season. Livestock export for the Hajj season starts 45 to 60 days before Eid al -Adha (festival of the sacrifice). In the example below, the Hajj period occurred between July and September and caused sharp increases in the export of small ruminants and

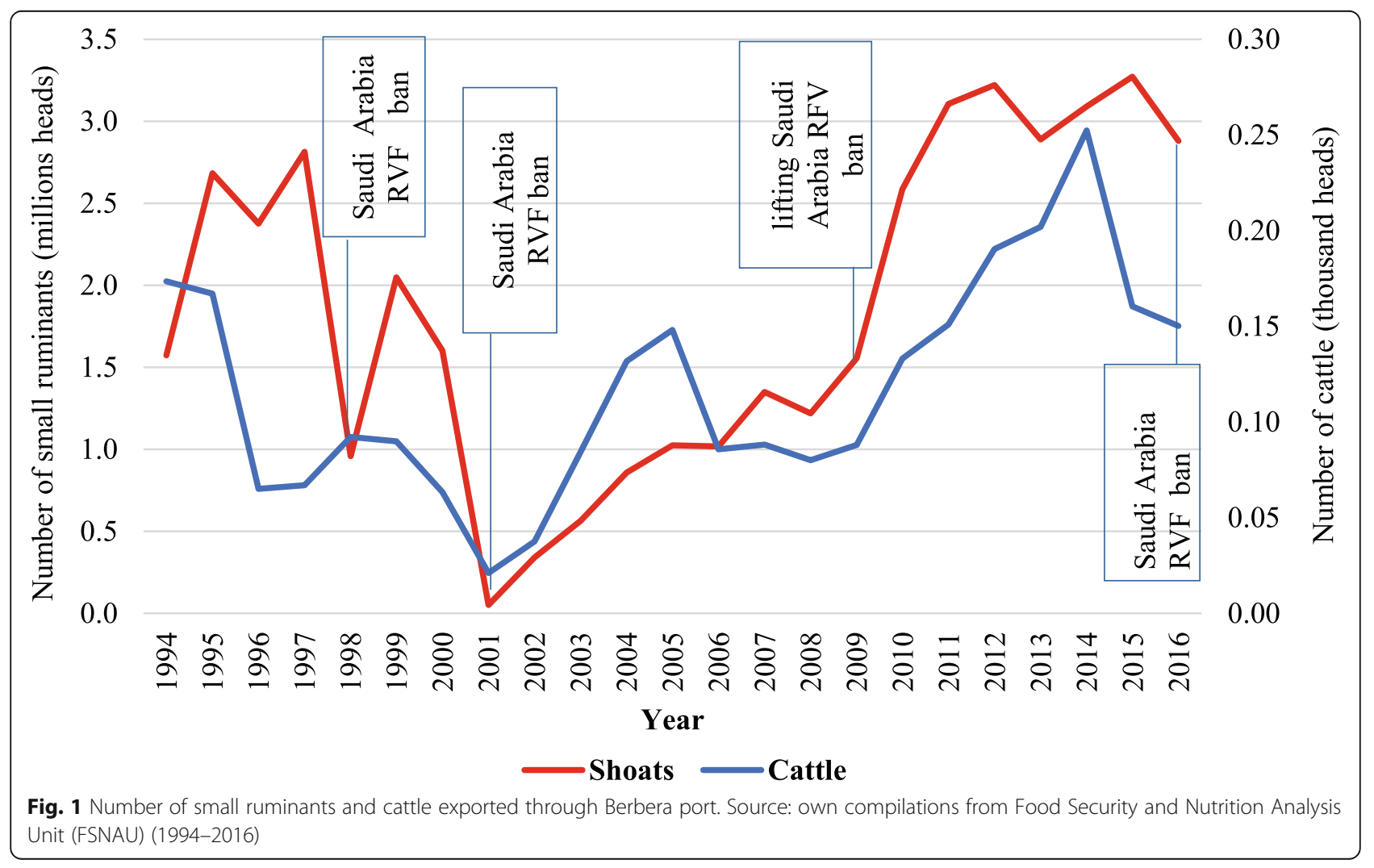




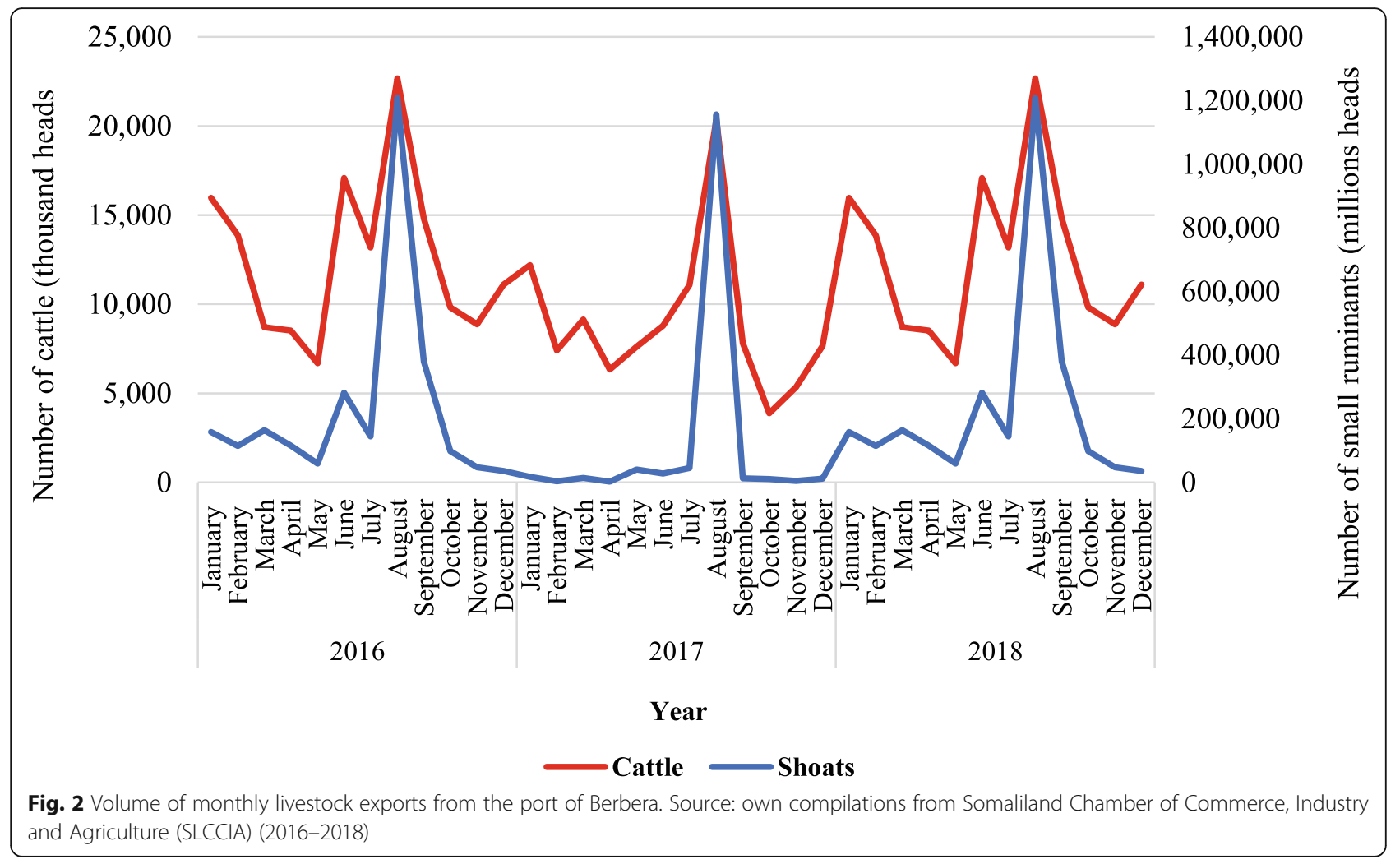

cattle. Despite severe drought across the HoA in 2016 and 2017 (FEWS NET 2017), livestock traders were able to mobilise millions of heads of small ruminants within a short period of time.

\section{Small ruminant export}

Livestock export through the port of Berbera stopped from 1988 after war broke out in northern regions of Somalia and export resumed in 1991. The volume of small ruminant export exceeded pre-war levels in mid-1990s (Little 2003). However, import countries imposed two consecutive and devastating bans on livestock export due to the outbreak of RVF. First, Saudi Arabia imposed a 14-month ban from February 7, 1988, to May 1999 (Majid 2010; Holleman 2002). The volume of export recovered after the ban was lifted and increased to 2.17 million heads of small ruminants exported by the end of 1999 (Holleman 2002). A second ban which lasted for 27 months from September 19, 2000, was imposed, this time, by all import countries in the Arabian peninsula (Saudi Arabia, Bahrain, Oman, Qatar, Yemen and the UAE) due to fear of RVF (Holleman 2002; Majid 2010; Eid 2014). This ban had severe effects and reduced livestock exports from 2 million to 50,000 heads by 2003 (Eid 2014). Except for Saudi Arabia, import countries lifted the second ban after 1 year (Majid 2010), while Saudi Arabia maintained the second ban up to November 2009.
Saudi Arabia lifted the prolonged ban after Somaliland granted licence to a Saudi investor who established a private quarantine station in Berbera to inspect and certify animal health before export (Phillips 2013; Eid 2014). During the ban on livestock export from Somalia's ports, including the port of Berbera, livestock export shifted to neighbouring Djibouti which has emerged as a competitive livestock export port since 2006 (Majid 2010; Eid 2014). Saudi Arabia imposed a third ban on Somaliland livestock import from December 2016 (Goobjoognews 2016), although the ban was temporarily suspended during the Hajj seasons to allow supply of livestock from Somalia ports.

\section{Cattle export}

Cattle constitutes the second highest population of live animals exported to the Arabian Peninsula, with Oman and Yemen being the main destination markets for cattle from the port of Berbera. An analysis from the yearly number of cattle exported from the port of Berbera between 1994 and 2016 indicates a sharp decline in 1996, 2001, 2006 and 2015. The volume of export remained almost constant between 1998 to 2000 , and there was a steep increase from 2002 to 2005 and from 2009 to 2014. Unlike small ruminants, the ban did not cause sharp declines in the yearly number of cattle exported. A plausible explanation could be that Saudi Arabia, the country responsible 
for most of the bans, banned cattle from Somalia in 1983 due to concerns about rinderpest disease (Aklilu and Catley 2009) and since then there were no direct cattle exports from Somalia to Saudi Arabia. The increase in cattle exports from 2002 could be attributed to the relocation of the cattle market from Hartasheikh market in Ethiopia, where there were trade restrictions such as ban on bulls younger than 3 years, to Togwajale market in Somaliland, where there were no restrictions (see Little et al. 2015; Umar and Baulch 2007).

\section{Methodology}

\section{Description of the study area}

Somaliland is located in a very arid area with irregular and unevenly distributed rainfalls, both spatially and temporarily, ranging from 100 to $450 \mathrm{~mm}$ per annum. There are two wet seasons and two dry seasons. The two wet seasons are Gu (spring) from April to June and Deyr (autumn) from October to December, and the two dry seasons are Jiilaal (winter) from January to March and Xagaa (summer) from July to September.

Historically, extensive livestock production and trade has been an important economic activity in Somaliland where pastoralism and agropastoralism are the main livelihood activities. Livestock trade, especially the export, is one of the main drivers of the country's economy. There are three lucrative and high-value terminal markets in Somaliland, namely Togwajale, Hargeisa and Burao. These markets are located in the major cities and the capital and close to transport hubs where final buyers transport animals to overseas markets (Umar and Baulch 2007) or slaughter in the major local cities. Togwajale market, which borders Ethiopia, specialises in cattle trade. It is estimated that a large number of the cattle traded in this market originate from the Oromia region of Ethiopia. Hargeisa and Burao markets specialise in small ruminants with most of the animals traded originating from the Somali region of Ethiopia and southcentral Somalia. Figure 3 shows the location of the study

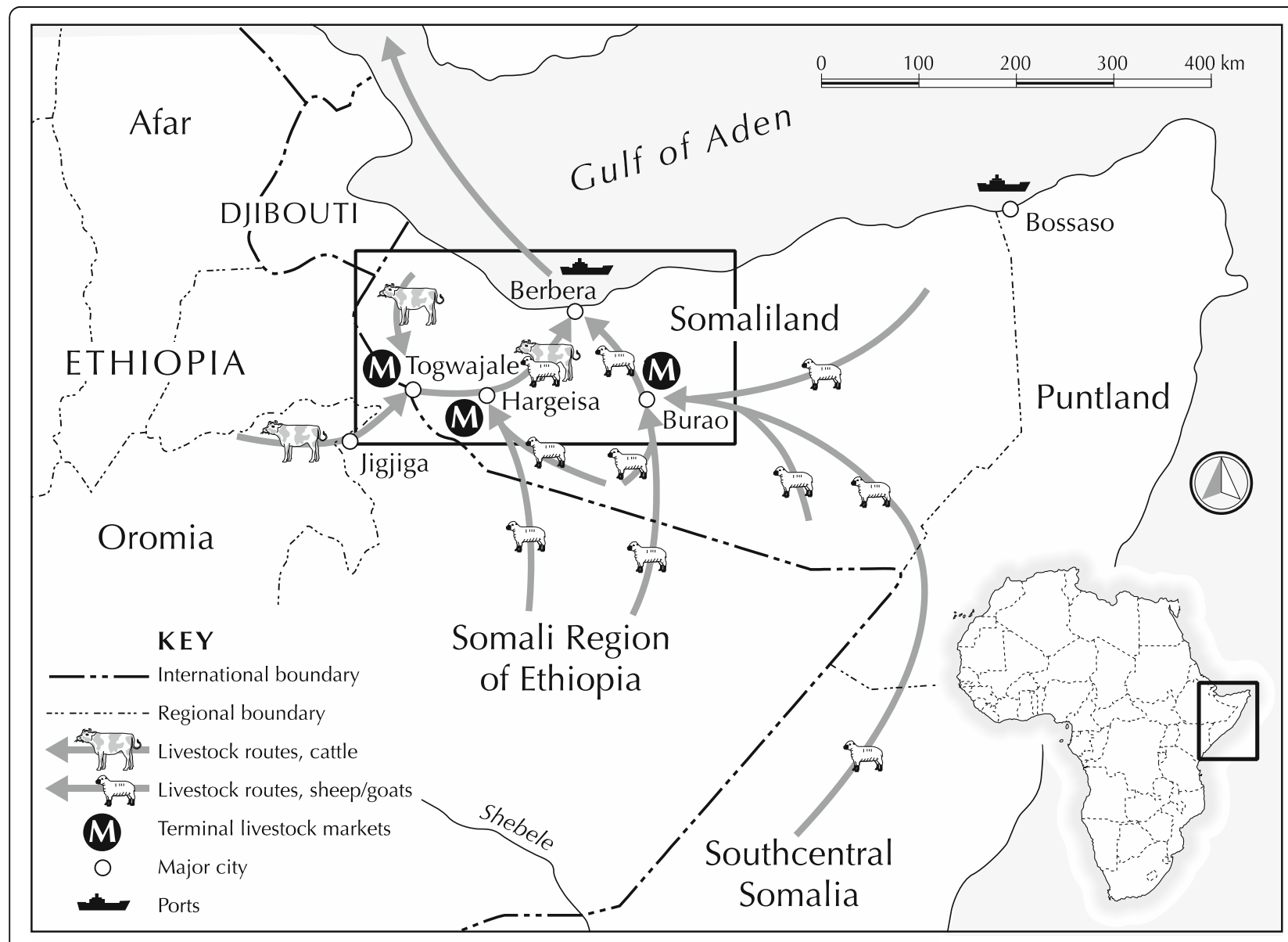

Fig. 3 Map showing study markets and feeding corridors 
sites (Hargeisa, Burao and Togwajale markets, and the port of Berbera).

\section{Data sources and analysis}

A dataset generated by the Somaliland Chamber of Commerce, Industry and Agriculture (SLCCIA) as part of the Livestock Marketing Information System (LMIS) was used to analyse the factors that influence the monthly number of livestock transacted for export in the study markets. SLCCIA has been systematically capturing the number of animals traded for export ('export quality'), animal prices and number of exporters active in Hargeisa and Burao markets for small ruminants and Togwajale market for cattle since mid-2007.

Using STATA 13 computer package, a multiple regression analysis was performed to determine the factors that influence the monthly number of livestock traded for export using time series secondary data of the monthly number of livestock traded for export in the three study markets for the period from 2008 to 2017. In addition, normality, autocorrelation, heteroskedasticity and non-stationarity tests were conducted prior to regression analysis. We tested the nonstationarity of the time series data using the PhillipsPerron test (Phillips and Perron 1988). The PhillipsPerron test is preferred for non-stationarity test because it produces consistent estimators of the variance (Rapsomanikis et al. 2003).
Determination of factors that influence the monthly volume of livestock transacted for export in the terminal markets

A generalised linear model was used to estimate Eqs. (1.1) and (1.2), this is because of the heteroskedasticity problem. We estimated one model for small ruminants and one for cattle because some explanatory variables that affect small ruminants do not affect cattle due to the difference in their value chains and import markets while there is also a significant difference in price and volumes of the two species. Variables and their descriptive statistics are presented in Tables 1 and 2.

\section{Model specification for small ruminants transacted for export in Hargeisa and Burao market}

The regression model for small ruminants was specified as below:

$$
\begin{aligned}
Y= & \beta_{0}+\beta_{1} X_{1 t}+\beta_{2} X_{2 t}+\beta_{3} X_{3 t}+\beta_{4} X_{4 t} \\
& +\beta_{5} X_{5 t}+\beta_{6} X_{6 t}+\beta_{7} X_{7 t}+\beta_{8} X_{8 t} \\
& +\beta_{9} X_{9 t}+\varepsilon
\end{aligned}
$$

where

$Y=$ monthly volume of small ruminants transacted for export in Hargeisa and Burao markets

$\beta_{0}-\beta_{9}=$ the estimated coefficients for $X_{i t}$

$X_{1 i t}=$ number of active exporters in the markets, $X_{2 i t}$

\begin{tabular}{|c|c|c|c|c|c|}
\hline Variable & Observations & Mean & Std. Dev. & Min & Max \\
\hline Number of small ruminants traded per month ${ }^{\mathrm{a}}$ & 236 & 88,013 & 133,921 & 530 & 753,300 \\
\hline Number of active exporters & 240 & 3 & 1.599 & 1 & 9 \\
\hline \multirow[t]{2}{*}{ Monthly average price (USD) } & 240 & 57 & 13.990 & 25 & 82 \\
\hline & \multicolumn{2}{|c|}{ Dummy variables } & Freq. & \multicolumn{2}{|l|}{ Percent } \\
\hline \multirow[t]{2}{*}{ Location of markets } & \multicolumn{2}{|l|}{ Hargeisa } & 120 & \multicolumn{2}{|l|}{50} \\
\hline & \multicolumn{2}{|l|}{ Burao } & 120 & \multicolumn{2}{|l|}{50} \\
\hline \multirow[t]{2}{*}{ Occurrence of the Hajj season } & \multicolumn{2}{|l|}{ Normal season } & 199 & \multicolumn{2}{|l|}{83} \\
\hline & \multicolumn{2}{|l|}{ Hajj season } & 41 & \multicolumn{2}{|l|}{17} \\
\hline \multirow[t]{2}{*}{ Access to quarantine } & \multicolumn{2}{|c|}{ No access to quarantine } & 42 & \multicolumn{2}{|l|}{70} \\
\hline & \multicolumn{2}{|c|}{ Access to quarantine } & 198 & \multicolumn{2}{|l|}{30} \\
\hline \multirow[t]{2}{*}{ Experience of Australia suspension of live animal export to Saudi Arabia } & \multicolumn{2}{|l|}{ No suspension } & 96 & \multicolumn{2}{|l|}{40} \\
\hline & \multicolumn{2}{|l|}{ Suspension } & 144 & \multicolumn{2}{|l|}{60} \\
\hline \multirow[t]{2}{*}{ Existence of ban } & \multicolumn{2}{|l|}{ No ban } & 66 & \multicolumn{2}{|l|}{27} \\
\hline & \multicolumn{5}{|l|}{ Ban } \\
\hline \multirow[t]{2}{*}{ Experience of drought } & \multicolumn{2}{|l|}{ No drought } & 182 & \multicolumn{2}{|l|}{77} \\
\hline & \multicolumn{2}{|l|}{ Drought } & 54 & \multicolumn{2}{|l|}{23} \\
\hline \multirow[t]{2}{*}{ Existence of border restrictions } & \multicolumn{2}{|c|}{ Border restriction } & 192 & \multicolumn{2}{|l|}{80} \\
\hline & \multicolumn{2}{|c|}{ No border restriction } & 48 & \multicolumn{2}{|l|}{20} \\
\hline
\end{tabular}
= occurrence of Hajj season, $X_{3 i t}=$ existence of livestock

Table 1 Descriptive statistics of variables used in the model for small ruminants

${ }^{a}$ There were four observations that were missing from the data on the monthly number of small ruminants transacted in Hargeisa and Burao markets for export which we treated as missing values 
Table 2 Descriptive statistics of variables used in the model for cattle

\begin{tabular}{|c|c|c|c|c|c|}
\hline Variable & Observations & Mean & Std. Dev. & Min & Max \\
\hline Number of cattle traded per month & 120 & 7895 & 2956 & 1142 & 16,476 \\
\hline Number of active exporters & 120 & 52 & 55 & 5 & 194 \\
\hline \multirow[t]{2}{*}{ Monthly average price (USD) } & 120 & 527 & 137 & 346 & 963 \\
\hline & \multicolumn{2}{|c|}{ Dummy variables } & \multicolumn{2}{|l|}{ Freq. } & Percent \\
\hline \multirow[t]{2}{*}{ Occurrence of the Hajj season } & \multicolumn{2}{|l|}{ Normal season } & \multicolumn{2}{|l|}{100} & 83 \\
\hline & \multicolumn{2}{|l|}{ Hajj season } & \multicolumn{2}{|l|}{20} & 17 \\
\hline \multirow[t]{2}{*}{ Access to quarantine } & \multicolumn{2}{|c|}{ No access to quarantine } & \multicolumn{2}{|l|}{21} & 18 \\
\hline & \multicolumn{2}{|c|}{ Access to quarantine } & \multicolumn{2}{|l|}{99} & 82 \\
\hline \multirow[t]{2}{*}{ Experience of ban } & \multicolumn{2}{|l|}{ No ban } & \multicolumn{2}{|l|}{87} & 73 \\
\hline & \multicolumn{2}{|l|}{ Ban } & \multicolumn{2}{|l|}{33} & 27 \\
\hline \multirow[t]{2}{*}{ Experience of drought } & \multicolumn{2}{|l|}{ No drought } & \multicolumn{2}{|l|}{93} & 77 \\
\hline & \multicolumn{2}{|l|}{ Drought } & \multicolumn{2}{|l|}{27} & 23 \\
\hline \multirow[t]{2}{*}{ Existence of border restrictions } & \multicolumn{2}{|c|}{ Border restriction } & \multicolumn{2}{|l|}{24} & 20 \\
\hline & \multicolumn{2}{|c|}{ No border restriction } & \multicolumn{2}{|l|}{96} & 80 \\
\hline
\end{tabular}

ban, $X_{4 i t}=$ existence of drought, $X_{5 i t}=$ access to a quarantine station, $X_{6 i t}=$ location of the market, $X_{7 i t}=$ average monthly price, $X_{8 t}=$ existence of Australia suspension of small ruminant export to Saudi Arabia and $\beta_{9} X_{9 t}=$ existence of Ethiopia border restrictions

\section{Model specification for the cattle transacted for export in Togwajale market}

The regression model for cattle was specified as below:

$$
\begin{aligned}
Y= & \beta_{0}+\beta_{1} X_{1 t}+\beta_{2} X_{2 t}+\beta_{3} X_{3 t}+\beta_{4} X_{4 t} \\
& +\beta_{5} X_{5 t}+\beta_{6} X_{6 t}+\beta_{7} X_{7 t}+\varepsilon
\end{aligned}
$$

where

$Y=$ monthly volume of cattle transacted for export in Togwajale market

$\beta_{0}-\beta_{7}=$ estimated coefficients for $X_{t}$

$X_{1 t}=$ number of active cattle exporters in market, $X_{2 t}$ = occurrence of Hajj season, $X_{3 t}=$ experience of livestock ban, $X_{4 t}=$ existence of drought, $X_{5 t}=$ access to livestock quarantine stations, $X_{6 t}=$ average monthly price and $X_{7 t}=$ existence of border restrictions

\section{Variables and their hypothesised influence on the dependent variable}

\section{Number of livestock transacted for export in the markets}

The monthly volume of livestock traded for export in the study markets was selected as the dependent variable and was estimated as the actual number of heads of cattle and small ruminants transacted in the study markets for the purpose of export to overseas markets during the period under study. SLCCIA collected the monthly volume of livestock transacted for export in the study markets from 2008 to 2017. The volume of livestock marketed was used as an indicator of market performance that is expected to be determined by multiple factors such as the number of livestock exporters active in the markets, occurrence of Hajj season, ban on livestock export, existence of quarantine stations, occurrence of drought, suspension of live animal export to Saudi Arabia by Australia and existence of border restrictions by Ethiopia.

For the independent variables and from the expectations about its positive or negative effects on livestock trade, we have grouped these variables into two groups: variables with expected positive effect and variables with expected negative effect.

\section{Number of active livestock exporters}

The number of active livestock exporters (ganasade/shirkad in Somali) in the study markets, sometimes represented by their agents (wakiil), was estimated as the number of livestock traders who had purchased animals for the purpose of exporting to overseas markets during the period under study. It was hypothesised that increase in the number of exporters in the markets will positively influence the number of livestock transacted as a higher number of exporters can be an indicator of market competition, more buyers, higher demand, higher price and therefore increase in the number of livestock traded for export in the markets.

\section{Occurrence of the Hajj season}

This variable was defined as a 60-day period between Eid al-Fitr (also known as Ramadan when Muslims celebrate for the end of their fasting season) and Eid al-Hajj (also known as Eid al-Adha when Muslims celebrate on the 10th day of Hajj). Adha is the practice of 
slaughtering/scarifying animals in commemoration of prophet Abraham (Umar and Baulch 2007). This study used this variable as a dummy having two categories represented by 0 (normal time of the year) and 1 (the period between Eid al-Fitr and Eid al-Adha). It was hypothesised that the number of livestock transacted for export in the study markets would increase during the Hajj season.

\section{Existence of a quarantine station}

This variable was defined as the period when official quarantine stations that inspect and certify livestock for export from Somaliland's port of Berbera were established. This variable is incorporated in the model as a dummy variable having two values: the period before September 2009 was assigned a value of 0 (no official quarantine stations were present to access) and 1 for the period starting from October 2009 when quarantine stations were established in Berbera port. Previous studies reported an increase in livestock export after the establishment of quarantine stations (Khadijah and Kabue 2012; Eid 2014). It was hypothesised that the number of livestock transacted for export increased after the establishment of quarantine stations.

\section{Suspension of live animal export to Saudi Arabia by Australia}

This variable was defined as the period when Australia, a key small ruminant producer/exporter, suspended its live animal export to Saudi Arabia, the main destination of Somaliland's small ruminant export. This variable was fitted into the model as a dummy having two values: 0 for the period before the Australia live animal export suspension and 1 for the period starting from 2012 when Australia suspended live animal export to Saudi Arabia. This study hypothesised that Australia's live animal suspension to Saudi Arabia will have a positive influence on the volume of small ruminants transacted for export in Somaliland since Australia is believed to be a major competitor of Somaliland livestock exports.

\section{Average monthly price of livestock}

This variable was estimated as the average monthly price of livestock transacted for export in the study markets. Price increase may have both a positive and negative influence on the volume of livestock traded. First, the increase in price may reduce demand in the end markets, and as a result, exporters may buy less livestock. Second, based on the assumption of increased demand in the end markets, traders and producers will market more livestock when the price is higher. In this study, it was hypothesised that the increase in price will lead to the increase in the volume of livestock transacted for export.

\section{Ban on livestock export}

Experience of export livestock ban was defined as the period when there was an official prohibition of livestock exports from Somaliland's Berbera port by the import countries. The value assigned to this dummy variable is 1 when livestock export ban was experienced and 0 otherwise. Previous studies reported a significant reduction in the volume of livestock export due to the ban (Umar and Baulch 2007; Eid 2014). It was hypothesised that the number of livestock transacted for export reduced during the period when there was a ban imposed by the import countries, particularly Saudi Arabia which is the main destination for Somaliland livestock export.

\section{Occurrence of drought}

This variable was defined as failure of expected rain in Somalia (all Somali regions) during the two wet seasons $G u$ from April to June and Deyr from October to December. The variable was incorporated into the model as a dummy variable having two categories: 0 when there was a no drought (expected rain was received) and 1 otherwise. Previous studies elsewhere in the region showed that drought had a negative effect on volumes of livestock trade due to the increased rate of animal mortality and producers' effort to recover the herd they lost during drought (Ayele et al. 2006). In this study, it was hypothesised that drought will have a negative influence on the monthly number of livestock transacted for export in the study markets.

\section{Existence of cross-border restrictions by Ethiopia}

Since 2010, Ethiopia has increased cross-border restrictions of livestock moving towards Somaliland for trade in an attempt to formalise cross-border livestock trade (Eid 2014). This variable was incorporated into the model as a dummy with two values: 0 for period before 2010 when there were limited border restrictions and 1 for the period from 2010 when Ethiopia increased crossborder livestock trade restrictions. This study hypothesised that increased border restrictions will reduce the monthly volume of livestock transacted in the study markets owing to the fact that $50 \%$ of small ruminants and over $80 \%$ of cattle transacted in study markets originate from eastern Ethiopia.

\section{Results}

Autocorrelation, normality, heteroskedasticity and nonstationarity tests were conducted prior to regression analysis. Autocorrelation test results showed no significant autocorrelation among the variables. Whereas there was no multi-collinearity problem, the data was not normally distributed and therefore the log of the dependent variable (monthly volume of livestock transacted for export) was used in the model instead of volume. We also tested 
if some of the variables in the regression model were highly correlated (i.e. multi-collinearity), and from the analysis, all variables had variance inflation factor (VIF) values less than 10 indicating that there was no multicollinearity problem in the data. Further, Breusch-Pagan test revealed evidence of heteroskedasticity in the model. This was corrected by using generalised least squares (GLS) as a method of analysis in order to reduce the variance. Finally, the time series data was found to be stationary.

\section{Factors affecting the number of small ruminants traded for export}

Results from the time series regression analysis for small ruminants transacted for export in Hargeisa and Burao markets are presented in Table 3. The results showed that the number of exporters active in Hargeisa and Burao markets has a positive and significant effect on the monthly volume of small ruminants traded for exports $(\exp (0.1596914)=1.173, p<0.01)$. This implies that a $1 \%$ increase in the number of exporters leads to a $17 \%$ increase in the number of small ruminants traded for export in the study markets. The Hajj season had a positive and significant influence on the monthly number of small ruminants transacted for export (exp $(1.512559)=4.538, p<0.01)$ which indicates that the number of livestock transacted for export increases by approximate 353\% during the Hajj season. Furthermore, the findings indicate that the average monthly price has a positive and significant influence on the monthly volume of small ruminants transacted for export (exp $(0.0164934)=1.016, p<0.05)$; this implies that a $1 \%$ increase in the price of animal leads to a $1.6 \%$ increase in

Table 3 Estimated parameters of factors affecting the number of small ruminants traded for export

\begin{tabular}{llll}
\hline Log volume & Coefficient & Std. Err. & $t$ \\
\hline Number of exporters & $0.1597^{* * *}$ & 0.0461 & 3.47 \\
Occurrence of Hajj & $1.5126^{* * *}$ & 0.1832 & 8.26 \\
Existence of quarantines & $0.7880^{*}$ & 0.4808 & 1.64 \\
Average of monthly price & $0.0165^{* *}$ & 0.0064 & 2.56 \\
Location of the markets & $0.6434^{* * *}$ & 0.1322 & 4.87 \\
Ban on livestock & $-1.5508^{* * *}$ & 0.2367 & -6.55 \\
Occurrence of drought & -0.2547 & 0.1704 & -1.49 \\
Australia livestock export suspension & -0.0579 & 0.1936 & -0.30 \\
Existence of border restrictions & -0.2469 & 0.4853 & -0.51 \\
Constant & $9.0097^{* * *}$ & 0.3848 & 23.41 \\
$R$ squared & 0.630 & & \\
$F$ value & 9.226 & & \\
Prob $>F$ & 0.000 & & \\
Number of observations & 236 & & \\
\hline$* * * 0<01 * * 0<0.05 * 0<0.1$ & & &
\end{tabular}

${ }^{* * *} p<0.01,{ }^{* *} p<0.05,{ }^{*} p<0.1$ the monthly number of small ruminants transacted for export. The location of the market has also a positive and significant effect on the monthly number of livestock traded for export $(\exp (0.6434526)=1.903, p<$ 0.01 ), showing that the monthly number of small ruminants transacted for export is $90 \%$ higher in Burao market compared to Hargeisa market. Access to quarantine stations has a positive and significant effect on the monthly volume of small ruminants traded for export $(\exp (0.7879699)=2.198, p=0.103)$, showing that the monthly number of small ruminants transacted for export has increased 119\% in Burao and Hargeisa markets since the quarantine stations were established.

The results also show that livestock ban imposed by the import countries, mainly Saudi Arabia, has a negative and significant effect on the monthly number of small ruminants transacted for export in the study markets $(\exp (-1.550827)=0.212, p<0.01)$, meaning during the ban, the monthly number of livestock traded for export in the study markets decreases by $78 \%$. Drought, Australia's suspension of export of small ruminants to Saudi Arabia and border restrictions imposed by Ethiopia have negative but statistically insignificant effects on the monthly number of small ruminants transacted for export.

\section{Factors affecting the number of cattle traded for export}

Results from the time series regression analysis for cattle transacted for export in Togwajale market are presented in Table 4. The results showed that the number of exporters active in Togwajale market has a positive and significant effect on the monthly volume of cattle transacted for exports $(\exp (0.003096)=1.0031, p<0.01)$. This implies that a $1 \%$ increase in the number of exporters led to a $0.31 \%$ increase in the number of cattle

Table 4 Estimated parameters of factors affecting the number of cattle traded for export

\begin{tabular}{llll}
\hline Log volume & Coefficient & Std. Err. & $t$ \\
\hline Number of exporters & $0.0031^{* * *}$ & 0.0007 & 4.46 \\
Occurrence of Hajj & $0.3786^{* * *}$ & 0.0678 & 5.58 \\
Ban on livestock & $0.2835^{* * *}$ & 0.0960 & 2.95 \\
Existence of quarantines & $0.6302^{*}$ & 0.3518 & 1.79 \\
Average of monthly price & 0.00007 & 0.0003 & 0.25 \\
Existence of border restrictions & -0.1004 & 0.3339 & -0.30 \\
Occurrence of drought & $-0.2254^{* * *}$ & 0.6119 & -3.68 \\
Constant & $8.1585^{* * *}$ & 0.1851 & 44.08 \\
$R$ squared & 0.5274 & & \\
F value & 7112 & & \\
Prob $>F$ & 0.000 & & \\
Number of observations & 120 & & \\
\hline
\end{tabular}

${ }^{* * *} p<0.01,{ }^{* *} p<0.05,{ }^{*} p<0.1$ 
traded for export. The Hajj season has a positive and significant influence on the monthly number of cattle transacted for export $(\exp (0.3786207)=1.4602, p<0.01)$ which indicated that the volume of cattle transacted for export increases by $46 \%$ during the Hajj season. Livestock ban had a positive and significant effect on the monthly volume of cattle traded for export (exp $(0.2834736)=1.3277, p<0.01)$. This showed that during ban, monthly cattle transacted for export increased by $32.7 \%$. The establishment of quarantine stations has a positive and significant effect on the monthly volume of cattle traded for export $(\exp (0.6302092)=0.878, p<$ 0.1 ), showing that the monthly number of cattle transacted for export has increased $87 \%$ in Togwajale markets since the quarantine stations were established.

Results show drought has a negative and significant effect on cattle traded for export $(\exp (-0.2253981)=$ $0.7981, p<0.01)$; this shows that cattle traded for export in Togwajale market decreased by $20 \%$ during the drought period, while border restrictions imposed by Ethiopia have a negative but statistically insignificant effect on the volume of cattle transected of export in this border market.

\section{Discussion}

Factors influencing the number of livestock traded for export in terminal markets along the Berbera corridor Livestock exporters

The results have indicated that the number of small ruminants transacted for export in the study markets increases with the number of exporters active in the markets. Exporters (ganasade/shirkad) are key market actors who purchase livestock from middle traders (jeeble) who assemble livestock from different sources in and outside Somaliland. Exporters act as the final link in the chain between local livestock trade and import markets (FEWS NET 2010); therefore, more active exporters in the local markets increase demand. Jeeble traders move livestock to where concentration of exporters and demand is higher (Umar and Baulch 2007).

In the study markets, government policies have influenced the number of livestock exporters. For example, in the late 1980s, the economic nationalisation of Somalia's government increased livestock exporters active in Hargeisa and Burao markets from 60 before nationalisation to 254 after nationalisation (Samatar et al. 1988). After 1991, the number of livestock exporters active in the study markets reduced to 4-5 monopolistic exporters (Nenova 2004). This was mainly due to Somaliland's fiscal policies such as the increase in export livestock taxation and the government requirement that livestock exporters exchange a certain percentage of livestock trade earnings in hard currency with the central bank at a very low exchange rate. These policies reduced profits that small-scale traders could make from livestock while only few large-scale exporters could make profits. Again, after 2009, Somaliland's decision to privatise quarantine stations to livestock exporters/quarantine station owners strengthened the monopoly in livestock export after lifting of the export ban to Saudi Arabia (Eid 2014).

\section{Hajj season}

The results indicate that the Hajj season has a significant influence on the number of livestock transacted for export in Somaliland's terminal markets. Findings from this study confirm the reported increase in livestock demand during this period. For example, Le Sage and Majid (2002) and Mugunieri et al. (2016) reported that the Hajj season generated a huge demand for small ruminants. The number of Muslim Hajj pilgrims to Saudi Arabia which has increased over time influences the number of livestock export during this season (Samatar et al. 1988; Godiah et al. 2014) as each pilgrim has to slaughter one animal as part of the Eid al-Adha ritual (Soumaré et al. 2006). Hajj is the primary driver of livestock export in the region (FEWS NET 2010). It is worth noting that there is a difference in terms of quality and sanitary requirements between the sacrificial (Hajj season) value chain and commercial value chain to Saudi Arabia (Costagli et al. 2017). A significant increase in the volume of livestock increase during the Hajj season indicates the increasingly seasonal nature of livestock export in Somaliland.

\section{Ban on livestock export}

Findings have demonstrated that the ban on livestock export imposed by the import countries significantly decreases the monthly volume of livestock transacted for export in Somaliland's terminal markets. Saudi Arabia, the main destination for small ruminant export, has repeatedly banned livestock export from Somalia/ Somaliland since 1998. The devastating effects of bans on livestock export were intensified by the fact that Somaliland is hugely dependent on the Saudi Arabia market for live animal exports - $80 \%$ of small ruminants are exported to Saudi Arabia (Mousley et al. 2015). The findings confirm those from previous studies, for example, Umar and Baulch (2007) reported that during the 2001 ban the volume of livestock export from northern Somali ports (Berbera and Bossaso) fell from 3.5 million heads of which 3.3 million was small ruminants to 0.7 million heads of which small ruminants accounted for 0.6 million. Eid (2014) also reported that the 2001 ban had seriously affected the port of Berbera, the main export port in the region; towards the end of 2003 livestock exports from port of Berbera fell from 2 million heads before the ban to 50,000 heads, which represented 
a 98\% drop on livestock exports. In the Horn of Africa, livestock bans are usually imposed by the import countries due to suspected or actual trans-boundary or epizootic livestock diseases (Aklilu and Catley 2009).

\section{Establishment of quarantine stations}

Findings show that access to quarantine stations has a positive and significant influence on the number of livestock traded for export in Somaliland's terminal markets. The official quarantine station in Somaliland had collapsed in 1991 due to the civil war. Though the absence of official quarantine stations did not preclude increased livestock export from Somaliland, it is believed that the absence of quarantine stations and official health standards had caused the 1998 and 2000 livestock bans (Holleman 2002). To find a solution for the repetitive bans, Somaliland permitted a Saudi investor to establish an official quarantine station in Berbera in 2009, and this had a positive influence on livestock export (Eid 2014). Since then, two more Arab investors established quarantine stations in Berbera. All Arab investors recruited former Somaliland livestock exporters (who were out of business due to the prolonged ban) as their agents (wakiils). Khadijah and Kabue (2012) reported that the establishment of quarantine stations in Berbera enhanced the confidence of import countries in the health of livestock exports from Somaliland.

It is noteworthy that in the last two decades, there has been an increased effort of the HoA countries to establish quarantine stations to provide health certification for animal export (Majid 2010). However, the presence of quarantine stations does not mean that HoA countries, including Somaliland, have met international livestock sanitary standards; rather, the import countries do not stringently implement World Trade Organization (WTO) health regulations for livestock trade which permit livestock traders from the HoA to export livestock without worrying much about animal traceability verification (Little et al. 2015). In addition, the establishment of quarantine stations did not open new livestock markets for Somaliland. One might plausibly argue that the establishment of private quarantine stations and animal certification have not been complemented with sound government policies, regulations and institutional capacity building to increase regulatory and supervisory oversight on the private quarantine stations or implement stringent animal health standards.

\section{Existence of drought}

Findings show that drought affects livestock trade negatively. However, the influence of drought on the number of small ruminants transacted for export was not statistically significant. There could be two plausible explanations for this phenomenon. First, the bulk of small ruminants transacted in the study markets originate from the Haud plateau, an area with environmental conditions suitable for small ruminant production in the rangelands that covers around $119,000 \mathrm{~km}^{2}$ extending from south of Hargeisa (the capital of Somaliland) to south-central Somalia and the Somali region of Ethiopia (Macfadyen 1950: 200). Often times, the intensity of drought in the Haud varies and pastoralists migrate to areas where drought intensity is low. Second, middle traders (jeebles) normally aggregate livestock from producers in the Haud and release to the markets during a period of high demand even when it coincides with a post-drought season. Elsewhere in the HoA, it has been reported that livestock sales increase during drought as pastoralists sell more livestock regardless of age, sex and quality in order to buy expensive grains, while livestock sales reduce after drought as pastoralists aim to recover their reduced herd size due to mass mortality and increased off take (Umar and Baulch 2007; Aklilu and Catley 2009; Pavanello 2010).

\section{Australia's suspension of live sheep export to Saudi Arabia}

Findings from this study have indicated that Australia's sheep export suspension to Saudi Arabia did not have a significant influence on the monthly volume of small ruminants transacted for export in Somaliland's terminal markets. Since 2012, Australia suspended its sheep exports to Saudi Arabia after Saudi Arabia felt that Australia's new animal welfare standards stipulated in Australia's Exporter Supply Chain Assurance Systems (ESCAS) were impinged on its sovereignty (Maritime 2017). Previous studies reported that small ruminant, especially sheep, export from Somaliland competes with Australia, the top sheep-exporting country in the world (Little et al. 2015). For example, in the late 1980s, livestock export from Somalia to the Arabian Gulf declined due to stiff competition from Australia (Mahmoud 2010). The findings of no significant influence from suspension of Australia sheep export to Saudi Arabia on the volume of small ruminants, especially sheep, from Somaliland's terminal markets could be explained by the fact that Australia's small ruminants are destined for a different consumer segment from the Somali small ruminants. Most of Somaliland livestock export is used for sacrificial slaughter during the Hajj season, which is different from the commercial livestock export to Saudi Arabia (Costagli et al. 2017) which livestock from Australia used to target. In addition, statistics from Saudi Arabia $^{2}$ show that in the last decade Sudan has emerged to be the leading small ruminants' exporter to Saudi Arabia. This implies that Australia is no longer a

\footnotetext{
${ }^{2}$ https://www.stats.gov.sa/en/214
} 
competitor to the Somali livestock export; rather, Sudan is the main competitor.

\section{Ethiopia's restrictions on cross-border livestock trade} Findings from this study indicated that Ethiopia's cross-border restrictions since 2010 had negative but insignificant effects on the monthly volumes of livestock transacted in the studied Somaliland terminal markets. From 2010, Ethiopia increased its border policing to restrict livestock crossing its borders informally to the neighbouring countries; this had adverse effects on traders and markets inEthiopia as the Togwajale market on the Ethiopia side of the border shifted to the Somaliland side (Eid 2014). The Somali community extends into eastern Ethiopia, and the long border between Somalia/Somaliland and Ethiopia historically remained largely porous. However, it is noteworthy that border restrictions since 2010 increased the cost of trade as local authorities in the trade routes charge higher levies and collect other informal fees from livestock crossing the border to Somaliland.

\section{Conclusion and recommendations}

The Hajj season, livestock export ban and number of exporters active in the study markets are the three most important determinants of the monthly volumes of livestock traded for export in Somaliland. The last two factors relate to policies; repeated bans indicate poor sanitary condition of livestock and failure to meet the sanitary requirements of the import countries, while due to Saudi and Somaliland government policies there are monopolistic exporters/quarantine station investors in the markets who impose price controls. In addition, the volume of export during the Hajj season indicates increasingly seasonal livestock trade and weakening of all-year round trade of livestock. These factors are related because all year round commercial value chain has declined due to poor sanitary reasons. Efforts to revive the vibrancy of the livestock exports from Somaliland should consider improving animal health and how to meet international sanitary standards which are acceptable to the import countries. On the one hand, this would require agreements and collaboration between the government of Somaliland and the Arabian Peninsula countries, especially Saudi Arabia, the main destination of Somaliland livestock export, to ensure that the two countries coordinate sanitary re-equipments, certification and regulatory mechanisms. On the other hand, Somaliland needs to strengthen its institutions, oversight authority and put in place all necessary mechanisms and infrastructures for improved livestock sanitary requirements.
Somaliland, like other countries in the region, has established quarantine stations to improve animal sanitary standards and privatised to Arab livestock traders with the aim to gain the confidence of the import countries and increase volumes of livestock trade. However, quarantine facilities alone are not the solution to the problems facing Somaliland livestock export; also necessary are comprehensive reforms and wider investment, including establishment of holding grounds and meeting appropriate sanitary standards such as proper implementation of internationally recommended quarantine periods and clinical screening of livestock while in the holding grounds for trans-boundary and zoonotic diseases. This would require participation of key stakeholders including livestock traders, exporters, quarantine investors and the local communities to address resistance and ensure compliance with the implementation of appropriate sanitary standards and regulations.

\section{Policy recommendations}

In order to realise the full potential of livestock export and make it more competitive, the Somaliland government should encourage the entry of additional livestock exporters into the business by addressing the issues related to the ownership and control of quarantine stations by influential exporters who are currently monopolising the export trade.

In order to restore year-round livestock trade between Somaliland and Saudi Arabia that has been curtailed by failure to meet sanitary standards, the Somali government needs to ensure stringent animal health standards and practices. This would require improving and upgrading the infrastructure (control laboratories, equipment); assessing the performance of its veterinary services and identifying the gaps; continuous training of the public and private veterinarians, implementing a certification system; and a livestock traceability system. These measures will have positive impacts on the animal health and reporting situation in Somaliland and increase trust with the importing countries.

The results reveal the important role played by the middle traders (jeebles) in smoothening the effect of drought by ensuring there is a supply of livestock for export even during and after drought periods in Somaliland. The jeebles provide outlets for livestock offtake before and during droughts, which serves as a destocking strategy for producers to avoid livestock losses associated with drought. In addition, the jeebles sell the aggregated stock after droughts when pastoralists barely offer their stock for sale as they focus on rebuilding their livestock flocks and herds. Given the role of livestock traders in cushioning the producers from drought losses, as well as in moderating the supply of livestock for export, there is a need to institutionalise the system 
practised by the jeebles, possibly by establishing grazing reserves that could be used to hold the animals and supporting fodder production to maintain the stock awaiting export.

Finally, since livestock supply to Somaliland's terminal markets relies on cross-border livestock trade, there is a need for the Government of Somaliland to negotiate for trans-boundary agreements and formalise cross-border livestock trade with the neighbouring countries, particularly Ethiopia, to allow free livestock movement across the countries and at the same time prevent transboundary diseases mainly fuelled by informal livestock trade.

\section{Abbreviations \\ ESCAS: Exporter Supply Chain Assurance Systems; FEWS NET: Famine Early Warning Systems Network; FSNAU: Food Security and Nutrition Analysis Unit; GDP: Gross Domestic Product; GLS: Generalised least squares; HoA: Horn of Africa; KSA: Kingdom of Saudi Arabia; LMIS: Livestock Marketing Information System; RVF: Rift Valley fever; SLCCIA: Somaliland Chamber of Commerce, Industry and Agriculture; UAE: United Arab Emirates; VIF: Variance inflation factor; WTO: World Trade Organization}

\section{Acknowledgements}

All authors thank the anonymous reviewers for their valuable comments which improved the quality of the paper.

\section{Authors' contributions}

AMM contributed by identifying the research problem, designing the study, compiling the date, carrying out the analysis and interpretation of the data, drafting the manuscript and submitting to this journal after the approval by the co-authors. OVW and NM contributed to the design of the study; provided technical and intellectual support during the analysis, interpretation and write-up of the data; and commented on all different drafts. All authors read and approved the final manuscript.

\section{Funding}

The authors thank the Governing Economic Hubs and Flows in Somali East Africa (GOVSEA) research programme and University of Nairobi's African Dryland Institute for Sustainability (ADIS) for financial and logistical support. Additional support for one of the co-authors was provided by the Livestock Agri-Food Systems (LAFS) CGIAR Program led by ILRI.The views expressed in the manuscript are those of the authors.

\section{Availability of data and materials}

The datasets used to analyse trends in livestock export through the port of Berbera from 1994 to 2016 are available on the Food Security and Nutrition Analysis Unit - Somalia (FSNAU)'s integrated database system, http://www. fsnau.org/ids/trade/index.php. The datasets used for the regression analysis have been compiled from the Livestock Marketing Information System (LMIS), livestock information database with Somaliland Chamber of Commerce, Industry and Agriculture, http://www.somalilandchamber.com/ ?page_id $=16$. The datasets generated for the variables fitted into the regression models are available from the corresponding author on request.

\section{Ethics approval and consent to participate}

Not applicable

\section{Consent for publication}

Not applicable

\section{Competing interests}

The authors declare that they have no competing interests

\section{Author details}

'Department of Land Resource Management and Agricultural Technology (LARMAT), University of Nairobi, PO Box 29053-00625, Nairobi, Kenya.
${ }^{2}$ International Livestock Research Institute (ILRI), PO Box 30709, Nairobi 00100 , Kenya.

Received: 6 June 2019 Accepted: 25 September 2019

Published online: 09 January 2020

\section{References}

Aklilu, Y. 2008. Livestock marketing in Kenya and Ethiopia: A review of policies and practice. Vol. 38. Addis Ababa: Feinstein International Center.

Aklilu, Y., and A. Catley. 2009. Livestock exports from the Horn of Africa: An analysis of benefits by pastoralist wealth group and policy implications. Medford: Feinstein International Center, Tufts University.

Ayele, G., M. Jabbar, H. Teklewold, E. Mulugeta, and G. Kebede. 2006. Seasonal and inter-market differences in prices of small ruminants in Ethiopia. Journal of Food Products Marketing 12 (4): 59-77.

Catley, A., J. Lind, and I. Scoones. 2013. Pastoralism and development in Africa: Dynamic change at the margins. Routledge.

Costagli, R., M. Godiah, and F. Wanyoike. 2017. A rapid appraisal of the Yemeni end-market for Somali livestock exporters. ILRI discussion paper 34. Nairobi: ILRI.

Diao, X., P. Hazell, and J. Thurlow. 2010. The role of agriculture in African development. World Development 38 (10): 1375-1383.

Eid, A. 2014. Jostling for trade: The politics of livestock marketing on the EthiopiaSomaliland border. Working Paper no. 75. Future Agricultures. Ethiopia.

FEWS NET [Famine Early Warning Systems Network]. 2010. Cross-border livestock trade assessment report. Impacts of lifting the livestock import ban on food security in Somalia, Ethiopia, and the Diibouti borderland. Famine Early Warning Systems Network. Nairobi: United States Agency for International Development.

FEWS NET [Famine Early Warning Systems Network]. 2017. 2016 Horn of Africa drought. Retrieved August 8, 2019, from https://fews.net/sites/default/files/ documents/reports/FEWS_NET_Horn_of_Africa_June\%202017_Drought_ Map_Book.pdf

Godiah, L., D. Baker, I. Elmi, R. Costagli, I. Gulaid, and F. Wanyoike. 2014. Enhancing the provision of livestock marketing information in Somaliland. In ILRI research report 35. Nairobi: ILRI.

Goobjoognews. 2016. Saudi Arabia bans Somali livestock again. Retrieved December 31, 2018, from https://goobjoog.com/english/saudi-arabia-banssomali-livestock/

Holleman, C. 2002. The socio-economic implications of the livestock ban in Somaliland. USAID: Nairobi. Available at: https://pdfs.semanticscholar.org/8c5 b/fb691 bd74884ffd83742903a000c9f5df635.pdf

Khadijah, K., and J. Kabue. 2012. Strengthening the quality infrastructure in Somaliland. A strategy for the livestock industry, Report Prepared for DANIDA IV Project. Nairobi: Terra Nuova EA.

Knips, V. 2004. Review of the livestock sector in the horn of Africa (IGAD countries). Livestock Sector Report Horn of Africa. Food and Agriculture Organization of the United Nations. Rome: Italy.

Le Sage, A., and N. Majid. 2002. The livelihoods gap: Responding to the economic dynamics of vulnerability in Somalia. Disasters 26 (1): 10-27.

Little, P. 2003. Somalia: Economy without state. Oxford: Bloomington: Hargeisa: Indiana University Press.

Little, P., W. Tiki, and D. Debsu. 2015. Formal or informal, legal or illegal: The ambiguous nature of cross-border livestock trade in the Horn of Africa. Journal of Borderlands Studies 30 (3): 405-421.

Macfadyen, W.A. 1950. Vegetation patterns in the semi-desert plains of British Somaliland. The Geographical Journal 116 (4/6): 199-211.

Mahmoud, H. 2010. Livestock trade in the Kenya, Somalia and Ethiopian borderlands, Briefing paper, BP 2010/02. Chatham House: London

Majid, N. 2010. Livestock trade in the Djibouti, Somali and Ethiopian borderlands, Briefing paper, BP 2010/02. Chatham House: London

Maritime executive. 2017. Australia, Saudi Arabia plan to restart live export trade. Retrieved December 31, 2018, from https://www.maritime-executive.com/ article/australia-saudi-arabia-plan-to-restart-live-export-trade

Ministry of National Planning and Development. 2017. Somaliland National Development Plan. https://sIministryofplanning.org/images/front-page/ Somaliland_NDPII

Mousley, P., J. Ndiaye, J. Wimpey, M. Amin, C. Votava, M. Nicoli, and D. Phillips. 2015. Somaliland's private sector at a crossroads: Political economy and policy choices for prosperity and job creation. World Bank Publications, Washington, DC. Available at https://doi.org/10.1596/978-1-4648-0491-5 
Mugunieri, L., R. Costagli, O. Osman, O. Oyieke, A. Jabbar, A. Negassa, and A. Omore. 2008. A rapid appraisal of institutions supporting Somali livestock export, ILRI Discussion Paper 14. Nairobi: International Livestock Research Institute (ILRI).

Mugunieri, G. L., Mtimet, N., Enock, K., Costagli, R., Gulaid, I. 2016. Saudi Arabia end-market requirements and the implications for Somaliland livestock exports. ILRI Research Report 40. Nairobi: International Livestock Research Institute (ILRI).

Negassa, A., R. Costagli, G. Matete, M. Jabbar, S. Oyieke, M. Abdulle, and A. Omore. 2008. Towards improving livestock export marketing support services in the Somali context: Survey findings and implications, ILRI discussion paper 35. Nairobi: ILRI.

Nenova, T. 2004. Private sector response to the absence of government institutions in Somalia. World Bank. Washington, DC. Available at: http://documents. worldbank.org/curated/en/248811468302977154/pdf/ 802300WPOSomalOBox0379802B00PUBLIC0.pdf

Pavanello, S. 2010. Livestock marketing in Kenya-Ethiopia border areas: A baseline study. Working paper: Humanitarian Policy Group (HPG) at Overseas Development Institute (ODI). London: United Kingdom

Phillips, A. 2013. Political settlements and state formation: The case of Somaliland (DLP research paper 23). Birmingham: Developmental Leadership Program, University of Birmingham.

Phillips, P.C., and P. Perron. 1988. Testing for a unit root in time series regression. Biometrika 75 (2): 335-346.

Rapsomanikis, G., Hallam, D., Conforti, P. 2003. Market integration and price transmission in selected food and cash crop markets of developing countries: review and applications. Commodities and Trade Division: Food and Agriculture Organisation (FAO): Rome

Samatar, A., L. Salisbury, and J. Bascom. 1988. The political economy of livestock marketing in Northern Somalia. African Economic History 17: 81.

Soumaré, B., E. Thys, D. Berkvens, A. Hashi, and G. Huylenbroeck. 2006. Effects of livestock import bans imposed by Saudi Arabia on Somaliland for sanitary reasons related to Rift Valley fever. Outlook on Agriculture 35 (1): 19-24.

Umar, A., and R. Baulch. 2007. Risk taking for a living. Trade and marketing in the Somali region of Ethiopia. UN-OCHA Pastoral Community Initiative.

\section{Publisher's Note}

Springer Nature remains neutral with regard to jurisdictional claims in published maps and institutional affiliations.

\section{Submit your manuscript to a SpringerOpen ${ }^{\circ}$ journal and benefit from:}

- Convenient online submission

- Rigorous peer review

- Open access: articles freely available online

- High visibility within the field

- Retaining the copyright to your article

Submit your next manuscript at $\boldsymbol{\nabla}$ springeropen.com 